\section{Current Outlook on Ice Encasement Stress and Management Strategies in Turfgrasses}

\author{
Emily Merewitz ${ }^{1}$
}

AdDitionAl INDEX WORDs. annual bluegrass, cool-season grasses, ice cover, Poa annua, winter preparatory management

SumMARY. Ice encasement of perennial cool-season turfgrasses is a common problem in many northern regions of the world, and the incidence of ice encasement may increase with climate change. The objective of this review was to discuss recent advances in knowledge of how ice encasement affects turfgrass systems, current knowledge gaps, and current and potential future management strategies that can be used by turfgrass managers to mitigate ice encasement damage to turfgrass species that are sensitive to this stress. Ice encasement is a complex and severe stress, which if prolonged can include low temperatures, anoxia, toxic gases, toxic metabolic by-products, and other complications associated with the stress. Thus, research is needed to specifically identify responses of different turfgrasses to this stress. Species such as annual bluegrass (Poa annua) are widespread in the turfgrass industry but do not have adequate tolerance of ice encasement and extensive plant necrosis can occur. Repairs or renovations of large areas damaged by ice encasement is costly. Research on ice encasement of turfgrass species is needed to provide efficient recommendations and management strategies to the turfgrass industry.

$\mathrm{P}$ erennial turfgrass species are susceptible to various winter stresses that can cause winterkill, such as low temperature stress, winter dehydration, freezing stress, spring freeze-thaws, and ice encasement. Despite their evolution in northern or temperate climates, cool-season turfgrasses (C3 photosynthetic pathway) experience winter-related injuries because these turfgrasses are under strict management, are subjected to intensive cultural practices, are not typically bred for winter survival traits, and are thought to be metabolically stressed due to some standard cultural management practices (Bell, 2011). Ice encasement can be experienced annually in many northern regions of the world or sporadically in some temperate areas, such as the northern United States, Canada, and other areas with similar weather patterns.

Climate change may cause an increase in ice encasement occurrence

Received for publication 30 June 2021. Accepted for publication 23 July 2021.

Published online 3 September 2021.

${ }^{1}$ Department of Plant, Soil, and Microbial Sciences, Michigan State University, East Lansing, MI 48824

E.M. is the corresponding author. E-mail: merewitz@msu.edu.

This is an open access article distributed under the CC BY-NC-ND license (https://creativecommons. org/licenses/by-nc-nd/4.0/).

https://doi.org/10.21273/HORTTECH04907-21 due to several factors, such as increased episodes of melting and freezing and reduced days of protective snow cover (Bélanger et al., 2002; Gudleifsson, 2009). The northern United States is projected to see $20 \%$ to $30 \%$ heavier precipitation in winter and spring (Easterling et al., 2017; Hayhoe et al., 2010). Ice encasement can be caused by freezing rain, ice storms, turf areas that have poor drainage, or wet fall seasons causing oversaturated soils followed by freezing temperatures, high levels of winter precipitation, or areas that have snow cover with freeze/thaw incidents that cause ice layer formation under the snow. Often, snow cover will conceal ice layers on the turfgrass canopy and be an unforeseen problem. Prolonged ice encasement can be extremely damaging to large turfgrass areas and costly to repair or renovate (Strandberg, 2007). A survey conducted in Scandinavia revealed an average annual cost estimate of repairing or recovering from winterkill damage (not only ice encasement) at $€ 35,000$ to $€ 40,000$ $(\approx \$ 40,000$ to $\$ 45,000)$ per golf course (Kvalbein et al., 2017). Similar economic analysis should be evaluated for other parts of the world. Ice encasement can also cause subsequent reductions in physiological performance. Periods of ice encasement during winter months can cause a marked loss in freezing tolerance such as in perennial ryegrass [Lolium perenne (Hoglind et al., 2010)] and annual bluegrass $[P$. annua (Hoffman et al., 2014)]. Thus, ice encasement incidence directly connects to spring freeze/thaw issues and premature deacclimation, a common problem in annual bluegrass.

The primary way to prevent ice encasement damage is to have ice encasement-tolerant turfgrasses growing in susceptible areas. Breeding cool-season turfgrasses for winter tolerance-associated traits has been minimal due to the complexity of winter stress, complex genomes of many turfgrass species, and lack of dedicated breeding programs to this problem because it is a challenging breeding target. The cool-season turfgrass species differ significantly in their tolerance to ice encasement. Creeping bentgrass (Agrostis stolonifera) and annual bluegrass are the two most common cool-season putting green species in northern areas, but other species can also be found, such as velvet bentgrass (Agrostis canina) and colonial bentgrass (Agrostis capillaris). These species differ significantly in their inherent ability to tolerate prolonged ice cover (Waalen et al., 2017). Annual bluegrass is more susceptible to ice cover damage because it can only survive an average of $60 \mathrm{~d}$ of ice cover compared with creeping bentgrass surviving $120 \mathrm{~d}$ or more of ice (Beard, 1964; Tompkins et al., 2004; Vargas and Turgeon, 2004). Colonial bentgrass and some fescue (Festuca) species, such as chewings fescue (Festuca rubra) have sensitivity to ice encasement like annual bluegrass (Waalen et al., 2017). In addition to genetically regulated tolerance, the environment or how each turfgrass species is managed may play a major role in determining winter survival of each species. This review outlines current knowledge of winter survival mechanisms of turfgrasses or plants in general, current management strategies that can be used to promote ice encasement survival of turfgrasses, and major knowledge gaps in our understanding of ice encasement that indicate future research needs.

\section{Types of ice encasement and turfgrass physiological damage}

The extent of damage due to ice cover is not only associated with 
turfgrass species but also related to the duration of ice and the type of ice that has formed. Ice layers can form in different ways, leading to either a porous or nonporous ice, which causes them to be permeable or impermeable to gases, respectively. Permeable or porous ice is typically not as detrimental to turf health when compared with impermeable sheets of ice. Porous ice allows for air movement between the bulk atmospheric and soil environment to the turfgrass plants, reducing the incidence of gas accumulation that could cause necrosis of crown tissue (Olien and Smith, 1981). Prolonged periods of impermeable or nonporous ice can readily cause anoxic conditions and buildup of toxic gases. Gases that were found to accumulate under ice sheets in turfgrasses include carbon dioxide, ethyl butyrate, and others (Aamlid et al., 2009). The lack of oxygen under impermeable ice layers can cause metabolites associated with anaerobic metabolism to build up in plant tissues, such as ethanol, lactate, malate, and others (Andrews, 1977; Gudleifsson, 1993). Anoxic conditions have been found to be exacerbated by soils with high respiration rates related to higher organic matter content in experiments with impermeable covers (Rochette et al., 2006). Thus, impermeable sheets of ice are considered the most damaging to ice encasement-sensitive turfgrass species, such as annual bluegrass due to the direct metabolic damaged caused by toxic gases and toxic metabolic by-products.

As crowns are the primary overwintering structure of most putting green species, the sensitivity of the crown tissue to anoxic conditions and toxic gases may determine ice encasement tolerance levels of each species. Toxic metabolites or gases accumulating in crown tissue cells can cause a general degradation of cell membranes during stress, which can cause electrolyte leakage and membrane dysfunction, likely due to lipid peroxidation (Andrews and Pomeroy, 1989; Hetherington et al., 1987). Research is needed to elucidate specifically how anoxic conditions and toxic gases specifically affect crown tissues and other turfgrass overwintering structures, like rhizomes, to identify methods that may promote protection and survival of prolonged impermeable ice conditions.
Other factors, such as the depth of ice, whether a plant is fully submerged or has leaf tissue above the ice layer (i.e., potential access to oxygen), and soil moisture during the ice encasement incident, may also play a role in the extent of damage to turfgrasses. Uneven turfgrass surfaces can allow for differing depths of ice accumulation, with the thicker ice formations causing more intense injury (Andrews and Pomeroy, 1975). Unsaturated soils have more air pockets and potentially allow for oxygen availability to plant tissues under ice encasement, making it less lethal to putting greens (Andrews, 1996). There can also be complications from ice encasement associated with toxic by-products trapped in the soil. During the thaw period and subsequent spring, soil can contain residual phytotoxic substances that limit seed germination. Brandsaeter et al. (2005) found that butyrate levels were high and could be a potential phytotoxin that limits germination. This would highly inhibit turfgrass reseeding as a potential remediation strategy to some previously ice-encased areas. Research that investigates how sand vs. soils with more organic matter influence ice encasement damage and subsequent complications would be beneficial to improve our understanding of ice encasement. In addition, research on soil health attributes such as using modern technology to evaluate microbiomes or how different microbial-based products may influence recovery from ice encasement may be warranted.

\section{Reaeration following ice encasement}

In addition to soil health concerns following ice encasement, during the spring warm-up period, plant tissues also may experience stress associated with the sudden reexposure to oxygen and light called postanoxic aeration or reaeration stress. The extent of lipid damage and damage to other cellular structures that can result from sudden reaeration can determine whether a plant is tolerant or sensitive to anoxia (Blokhina et al., 1999). Plants have an antioxidant system to defend their cells from oxidative stress and the responsiveness of this system could play a role in reaeration stress levels (Blokhina et al., 2001). Most reaeration stress research has been on flooding, simulated anoxic stress with controlled conditions, or other causes of anoxia in plant systems. Additional investigation into turfgrass responses to reaeration following ice encasement (i.e., at lower and increasing temperatures) is needed. Laskowski and Merewitz (2021) found that low temperature alone $\left[-4^{\circ} \mathrm{C}\left(24.8^{\circ} \mathrm{F}\right)\right]$ and ice encasement at $-4^{\circ} \mathrm{C}$ caused an increase in lipid peroxidation to similar levels in both leaves and crown tissue. Unexpectedly, crowns were not more resilient to the development of lipid peroxidation than leaves in that study. The sensitivity of annual bluegrass to ice encasement could be related to lack of a powerful antioxidant system to prevent lipid or oxidative damage to crown tissues. In the same study, ice encasement did not cause changes in fatty acid composition of plant membranes compared with low temperature alone. Management strategies that may promote crown health by targeting biochemical pathways, such as antioxidant systems or the health of plant membranes, may be desirable.

CURRENT WINTER MANAGEMENT STRATEgIES. Because of all the potential damage and complications associated with ice encasement, turfgrass managers should monitor for not only the presence of ice encasement but also try to understand the cause of layer formation, monitor the duration of ice persistence, evaluate ice depth, and identify ice type (porous vs. nonporous) before executing management strategies discussed later in this article. Turfgrass managers, particularly athletic field managers and golf course superintendents, do have methods for alleviating ice encasement occurrence and stress, but these methods are typically limited to small areas such as an athletic field or putting green surfaces. Mechanical removal of ice or ways to increase drainage are commonly used to reduce standing water or move melt water away from turf surfaces (Frank, 2016; Quinn, 1990). The decision to physically remove snow or ice is typically based on the duration of ice and which species is present in a turf area. For instance, turfgrass managers may decide to remove ice from annual bluegrass putting greens if the ice may persist for more than $40 \mathrm{~d}$. These methods can be labor intensive and destructive to the putting green surface, 
such as by causing scuffing, scalping, compaction of soil, traffic damage (i.e., crushing) of water soaked and sensitive grass crowns, and other damage. Whether heavy machinery or shovels are used will certainly influence the extent of damage caused by mechanical removal of ice. Pros vs. cons of physical removal need to be weighed.

Other methods include applying top-dressing materials, such as heavy layers of sand, colored sand, dark materials to harness solar warming, salts, and other compounds to melt snow and ice. Turfgrass managers also commonly use permeable or impermeable covers and their combination before snow in the fall season to protect putting greens or athletic fields (Frank, 2016). Permeable covers will allow for gas exchange, but they can allow ice layers to accumulate under the cover. Impermeable covers allow for no ice or water to reach the turf putting green canopy; however, they do not allow for adequate gas exchange to occur. This results in venting of the putting green to be required so that gas exchange can occur periodically (Rochette et al., 2006). Unseasonal temperatures such as late warm fall periods or early warm spring periods followed by cold make it difficult to know when the right time is to apply covers. It can also be costly to purchase covers and labor intensive to install cover systems.

POTENTIAL MANAGEMENT STRATEGIES. Solutions that can be used on larger turf areas, are less labor intensive, and have fewer drawbacks, such as difficulty in timing management strategies due to annual weather changes, are needed to improve turfgrass tolerance to ice encasement stress. Climate change may increase ice encasement incidence and freeze/thaw periods in spring. Chemical applications of protective compounds or plant growth regulators (PGRs) have been proposed to increase turfgrass overwinter survival for large areas. To adequately develop these proposed methods, a better understanding of the physiological relationships between cold acclimation and ice encasement tolerance and spring recovery is needed.

It may be possible to alter or regulate physiological properties occurring during cold acclimation to increase tolerance to ice encasement stress or allow for adequate resource conservation or storage for survival and recovery.
Specific processes associated with plant acclimation include photosynthesis and respiration changes, carbohydrate allocation, plant water relations, shifts in membrane composition (fatty acids), hormone responses, and other metabolite changes (Thomashow, 1999). Turfgrass species exhibit differential mechanisms associated with cold acclimation. For instance, when carbohydrate metabolism begins to change in productivity during acclimation or become minimal during dormancy may influence overwintering and winter stress survival. Low respiration of winter wheat and some cool-season grasses has been shown to increase survival to winter conditions (Bertrand et al., 2003; Sagisaka et al., 1991). Identifying important traits such as photosynthesis and respiration rates during cold acclimation and how those processes may be altered by winter preparatory treatments to prepare turfgrasses for ice encasement survival needs additional investigation.

Some PGRs and plant protective treatments have been shown to influence traits associated with cold acclimation and cold tolerance in turfgrasses and may improve ice encasement survival. For instance, annual bluegrass treated with a mineral oil product [Civitas Turf Defense (Civitas); PetroCanada, Mississauga, ON, Canada], mefluidide, and propiconazole had the highest amount of regrowth after ice and low temperature without ice treatments and shifts in fatty acid composition that were indicative of greater cold tolerance (Laskowski et al., 2018). It is not yet clear whether these treatments are directly influencing ice encasement-related stresses, such as toxic gas tolerance or anoxia tolerance, or are indirectly promoting ice encasement survival via altered acclimation traits. Laskowski and Merewitz (2021) found that some chemical treatments, such as a mineral oil product (Civitas), did influence the response of the antioxidant system and had greater membrane health following ice encasement, which could correlate to greater levels of regrowth during the post ice encasement reaeration.

Conversely, some PGRs may reduce turfgrass survival of winterrelated stresses such as ice encasement. PGRs that inhibit gibberellic acid (GA) biosynthesis showed some evidence of reducing annual bluegrass tolerance to ice encasement and promoted loss of freezing tolerance, but the results were not always consistent in each year (DaCosta et al., 2021; Laskowski et al., 2018). This is important because PGRs that inhibit GA biosynthesis are the most applied PGRs in the turfgrass industry to reduce mowing frequency and for other purposes. Trinexapacethyl is a commonly used PGR on golf course putting greens to inhibit late GA biosynthesis, which limits vertical leaf growth (Adams et al., 1992). Additional work to understand how inhibiting GA and other plant hormones relates to winter stress tolerance and cold acclimation is needed.

Ethylene is another important stress-associated plant hormone that could be regulated with PGRs to either increase or decrease winter and ice encasement tolerance of turfgrasses (Laskowski and Merewitz, 2020a, 2021). Ethephon treatments, which increase ethylene evolution in plant tissues, had greater levels of lipid damage, less antioxidant activity, and lower regrowth compared with control untreated annual bluegrass plants (Laskowski and Merewitz, 2020a, 2021). Ethephon is commonly used on annual bluegrass to control seed head production (Eggens et al., 1989). Conversely, inhibiting ethylene with an aminoethoxyvinylglycine-containing PGR improved annual bluegrass regrowth after 40 or $80 \mathrm{~d}$ of exposure to $-4^{\circ} \mathrm{C}$ with or without ice cover by using experimental conditions that involved natural acclimation in the field, fall treatments of PGRs, and ice encasement or no ice at low temperatures in controlled environment chambers (Laskowski and Merewitz, 2020a). Treatments that inhibit turfgrass canopy ethylene production may be a potential management strategy to improve annual bluegrass winter survival of ice encasement conditions without any negative effects on creeping bentgrass, which is an important consideration because many putting greens are a mix of annual bluegrass and creeping bentgrass. Testing of these treatments for ice encasement survival entirely in the field for several years is still needed, and research elucidating mechanisms of ethylene regulation of winter stresses is needed in turfgrass species.

Other protective plant compounds, such as those that illicit or induce plant defense responses, may 
be used to prime plants for enhanced stress tolerance (Merewitz, 2016). In the turfgrass industry, these primingtype compounds are primarily used for improving resistance to biotic pathogens. An example is azibenzolars-methyl, an analog of salicylic acid, and others that induce defense via salicylic acid (Jespersen et al., 2017) or jasmonic acid disease defense response pathways (Liu et al., 2017). Salicylic and jasmonic acids are both plant hormones that signal systemic or local defense responses and can contribute to tolerance or sensitivity to abiotic stresses (Liu et al., 2018). When these compounds are routinely used during the growing season for improved resistance to biotic stress, what does that do to the turf's ability to overwinter and tolerate abiotic stress? Little information exists to answer this question. Priming agents such as jasmonic acid alone or in combination with a mineral oil product (Civitas) or trinexapac-ethyl aided annual bluegrass in ice encasement recovery (Laskowski and Merewitz, 2020b). Priming agents in combination with trinexapac-ethyl, which was previously thought to possibly reduce ice encasement tolerance, showed enhanced regrowth following ice encasement. Thus, priming agents that target jasmonic acid pathways may be important for winterkill-associated stresses. Treating annual bluegrass with salicylic acid did not illicit a significant or consistent change in annual bluegrass survival of low temperature or ice encasement. Additional research, such as field studies or more detailed biochemical studies, are needed to better understand the role of jasmonic and salicylic acid in turfgrass overwintering stresses.

\section{Conclusions}

Species and cultivar variation in ice encasement survival exists and tolerant germplasm is typically the best line of defense against environmental stresses. In the face of climate change, the turfgrass industry would benefit greatly from increased efforts of breeding programs to investigate winter tolerance-associated traits. Breeding has been difficult for some highly ice encasement-sensitive species, like annual bluegrass, with no commercially available cultivars released. Thus, breeding will not be the only solution with usable outcomes. Improving our knowledge of physiological mechanisms associated with traits such as ice encasement tolerance, development of modern sensing technologies to predict or validate the presence of winter stress conditions, and management strategies may be our best way forward to develop readily applicable strategies to increase turfgrass winter survival for both the short- and long-term success of the turfgrass industry.

\section{Literature cited}

Aamlid, T.S., P.J. Landschoot, and D.R. Huff. 2009. Tolerance to simulated ice encasement and Microdochium nivale in USA selections of greens-type Poa annua. Acta Agr. Scand. 59:170-178, doi: 10.1080/09064710802093854.

Adams, R.E., E. Kerber, K. Pfister, and E.W. Weiler. 1992. Studies on the action of the new growth retardant CGA 163'935 (Cimectacarb), p. 818-827. In: C.M. Karssen, L.C. van Loon, and D. Vreugdenhil (eds.). Progress in plant growth regulation. Kluwer Academic Publishers, Dordrecht, The Netherlands, doi: 10.1007/978-94011-2458-4_100.

Andrews, C.J. 1977. Accumulation of ethanol in ice-encased winter cereals. Crop Sci. 17:157-161, doi: 10.2135/ cropscil977.0011183X00170001004lx.

Andrews, C.J. and M.K. Pomeroy. 1989. Ice-encasement injury at the cellular and membrane level. Icel. Agr. Sci. 2:57-61, doi: 10.1104/pp.85.4.1068.

Andrews, C.J. and M.K. Pomeroy. 1975. Survival and cold hardiness of winter wheat during partial and total ice immersion. Crop Sci. 15:561-566.

Andrews, C.J. 1996. How do plants survive ice? Ann. Bot. 78:529-536.

Beard, J.B. 1964. Effects of ice, snow and water covers on kentucky bluegrass, annual bluegrass and creeping bentgrass. Crop Sci. 4:638-640.

Bélanger, G., P. Rochette, Y. Castonguay, A. Bootsma, D. Mongrain, and D.A.J. Ryan. 2002. Climate change and winter survival of perennial forage crops in eastern Canada. Agron. J. 94:1120-1130, doi: 10.2134/ agronj2002.1120.

Bell, G.E. 2011. Turfgrass physiology and ecology: Advanced management principles. CABI, Cambridge Univ. Press, Cambridge, UK.

Bertrand, A., Y. Castonguay, P. Nadeau, S. Laberge, P. Rochette, R. Michaud, G. Belanger, and P. Rochette. 2003. Oxygen deficiency affects carbohydrate reserves in overwintering forage crops. J. Expt. Bot. 54:1721-1730, doi: 10.1093/jxb/erg182.

Brandsaeter, L.O., E. Haugland, M. Helgheim, B.E. Gudleifsson, and A.M. Tronsmo. 2005. Identification of phytotoxic substances in soils following winter injury of grasses as estimated by a bioassay. Can. J. Plant Sci. 85:115-123, doi: 10.4141/ P03-075.

Blokhina, O.B., T.K. Chirkova, and K.V. Fagerstedt. 2001. Anoxic stress leads to hydrogen peroxide formation in plant cells. J. Expt. Bot. 52:1179-1190, doi: 10.1093/ jexbot/52.359.1179.

Blokhina, O.B., K.V. Fagerstedt, and T.K. Chirkova. 1999. Relationships between lipid peroxidation and anoxia tolerance in a range of species during post-anoxic reaeration. Physiol. Plant. 105:625-632, doi: 10.1034/j.1399-3054.1999.105405.x.

DaCosta, M., J.S. Ebdon, K. Miele, R.P. Bernstein, and J.C. Inguagiato. 2021. Plant growth regulator effects on winter hardiness of annual bluegrass putting green turf. Intl. Turfgrass Soc. Res. J. 2021:1-11, doi: 10.1002/its2.6.

Eggens, J.L., C.P.M. Wright, D.P. Murr, and K. Carey. 1989. The effect of ethephon on annual bluegrass and creeping bentgrass growth. Can. J. Plant Sci. 69:1353-1357.

Easterling, D.R., K.E. Kunke, J.R. Arnold, T. Knutson, A.N. LeGrande, L.R. Leung, R.S. Vose, D.E. Waliser, and M.F. Wehner. 2017. Precipitation change in the United States. U.S. Dept. Commerce GSFC-E-DAA-T N49608, doi: 10.7930/J0H993CC.

Frank, K. 2016. The war on winter: Preparing your turfgrass for the snowy, icy, frigid months. GreenMaster 51:22-23.

Gudleifsson, B.E. 1993. Metabolic and cellular impact of ice encasement on herbage plants. In: M.B. Jackson and C.R. Black (eds.). Interacting stresses on plants in a changing climate. Vol. 16. NATO ASI Series I: Global Environmental Change. Springer, Berlin/Heidelberg, Germany, doi: 10.1007/978-3-642-78533-7_26.

Gudleifsson, B.E. 2009. Ice encasement damage on grass crops and alpine plants in Iceland-Impact of climate change, $\mathrm{p}$. 163-172. In: L. Gusta, M. Wisniewski, and K. Tanino (eds.). Plant cold hardiness: From the laboratory to the field. CABI, Cambridge, MA.

Hayhoe, K., J. VanDorn, T. Croley, N. Schlegal, and D. Wuebbles. 2010. Regional climate change projections for Chicago and the U.S. Great Lakes. J. Great Lakes Res. 36:7-21, doi: 10.1016/j.jglr.2010.03.012.

Hetherington, P.R., B.D. McKersie, and A. Borochov. 1987. Ice encasement injury 
to microsomal membranes from winter wheat crowns: I. Comparison of membrane properties after lethal ice encasement and during a post-thaw period. Plant Physiol. 85:1068-1072.

Hoffman, L., M. DaCosta, and J.S. Ebdon. 2014. Examination of cold deacclimation sensitivity of annual bluegrass and creeping bentgrass. Crop Sci. 54:413-420, doi: 10.2135/cropsci2013.05.0329.

Hoglind, M., A.K. Bakken, M. Jørgensen, and L. Østrem. 2010. Tolerance to frost and ice encasement in cultivars of timothy and perennial ryegrass during winter. Grass Forage Sci. 65:431-445, doi: 10.1111/j.1365-2494.2010.00762.x.

Jespersen, D., J. Yu, and B. Huang. 2017. Metabolic effects of acibenzolar-s-methyl for improving heat or drought stress in creeping bentgrass. Front Plant Sci. 8: 1224, doi: 10.3389/fpls.2017.01224.

Kvalbein, A., W.M. Waalen, L. Bjornstad, and T.S. Aamlid. 2017. Winter injuries on golf greens in the nordic countries: Survey of causes and economic consequences. Intl. Turfgrass Soc. Res. J. 13:604-609, doi: 10.2134/itsrj2016.09.0826.

Laskowski, K., K. Frank, and E. Merewitz. 2018. Chemical plant protectant and plant growth regulator effects on annual bluegrass survival of ice cover. J. Agron. Crop Sci. 205:202-212, doi: 10.1111/ jac.12309.

Laskowski, K. and E. Merewitz. 2020a. Ethylene regulatory treatment effects on annual bluegrass survival of freezing temperature and ice cover. Agron. J. 112: 861-870, doi: 10.1002/agj2.20030.

Laskowski, K. and E. Merewitz. 2020b. Chemical priming to improve annual bluegrass survival of ice encasement. Agron. J. 112:5002-5011, doi: 10.1002/ agj2.20420.

Laskowski, K. and E. Merewitz. 2021. Influence of ice and ethylene regulation on cellular protection mechanisms in annual bluegrass. J. Amer. Soc. Hort. Sci. 146: 87-98, doi: 10.21273/JASHS05000-20.

Liu, S., J. Vargas, and E. Merewitz. 2017. Phytohormones associated with bacterial etiolation disease in creeping bentgrass. Environ. Exp. Bot. 133:35-49, doi: 10.1016/j. envexpbot.2016.09.004.

Liu, S., J. Vargas, and E. Merewitz. 2018. Jasmonic and salicylic acid treatments reduce bacterial etiolation disease of creeping bentgrass in optimal and high temperatures. Crop Prot. 109:9-16, doi: 10.1016/ j.cropro.2018.02.023.

Merewitz, E. 2016. Priming-induced drought stress tolerance in plants, $\mathrm{p}$. 77-103. In: M. Hossain, S. Wani, S. Bhattacharjee, D. Burritt, and L.S. Tran. (eds.). Drought tolerance in plants. Springer, New York, NY.

Olien, C.R. and M.N. Smith. 1981. Recovery from winter Injury, p. 117-138. In: C.R. Olien and M.N. Smith (eds.). Analysis and improvement of plant cold hardiness. CRC Press, Boca Raton, FL.

Quinn, P. 1990. Coping with snow and ice: As winter approaches, superintendents share their techniques and concerns. Golf Course Manage. 58:89-91.

Rochette, P., J. Dionne, Y. Castonguay, and Y. Desjardins. 2006. Atmospheric composition under impermeable winter golf green protections. Crop Sci. 46:1644 1655, doi: 10.2135/cropsci2005.05-0074.

Sagisaka, S., T. Matsuda, T. Okuda, and S. Ozeki. 1991. Relationship between wintering ability of winter wheat and the extent of depression of carbohydrate reserves: Basal metabolic rate under snow determines longevity of plants. Soil Sci. Plant Nutr. 37:531-541.

Strandberg, M. 2007. Winter injury on golf courses. Swedish Golf Federation, Danderyd, Sweden.

Thomashow, M.F. 1999. Plant cold acclimation: Freezing tolerance genes and regulatory mechanisms. Annu. Rev. Plant Physiol. Plant Mol. Biol. 50:571-599.

Tompkins, D.K., J.B. Ross, and D.L. Moroz. 2004. Effects of ice cover on annual bluegrass and creeping bentgrass putting greens. Crop Sci. 44:2175-2179, doi: $10.2135 /$ cropsci 2004.2175.

Vargas, J.M. and A.J. Turgeon. 2004. Poa annua: Physiology, culture, and control of annual bluegrass. Wiley, Hoboken, NJ.

Waalen, W.M., T. Espevig, A. Kvalbein, and T.S. Aamlid. 2017. The effect of ice encasement and protective covers on the winter survival of six turfgrass species on putting greens. Intl. Turfgrass Soc. Res. J. 13:556565, doi: 10.2134/itsrj2016.05.0432. 